\title{
Development of bioassay for pathogenecity testing of Ureaplasma urealyticum as part of host-pathogen communication
}

\author{
Purnomo Soeharso
}

\begin{abstract}
Abstrak
Bioesei Ureaplasma urealyticum perlu dikembangkan sebagai teknik untuk mendeteksi dan mendeterminasi faktor patogen bakteri, sehingga patogenesis penyakit yang disebabkan infeksi ureaplasma dapat dipahami dengan baik. Tahap pertama penelitian ini adalah mengembangkan metoda untuk kultivasi dan verifikasi ureaplasma; kultivasi pada media padat maupun cair dapat digunakan untuk mendeteksi ureaplasma dalam sampel yang diperiksa. Meskipun demikian teknik PCR yang mengamplifikasi DNA bakteri menggunakan primer yang meliputi gen urease (ure) lebih memberikan konfirmasi yang akurat tentang keberadaan U. urealyticum. Untuk memahami patogenisitas ureaplasma, uji expresi gen menggunakan gen reporter yang berfungsi sebagai penanda (marker) expresi dapat digunakan untuk membuktikan aktifitas gen yang membawa sifat patogen bakteri. Gen iceC dapat digunakan sebagai gen reporter untuk mendeterminasi patogenisitas ureaplasma karena gen ini mempunyai keunggulan sangat sensitif, mudah dideteksi dan diukur aktifitasnya menggunakan uji pembekuan es (ice nucleation assay). Patogenesis penyakit juga dapat dipantau dengan uji mutagenesis in vitro, dimana gen kompeten untuk patogenisitas bakteri diinaktifkan dengan menginsersikan gen penanda (marker) dalam proses transformasi bakteri. IgAl protease merupakan enzim ureaplasma yang menentukan patogenisitas dan diperlukan untuk kolonisasi bakteri pada situs infeksi, sehingga identifikasi gen iga dan uji aktifitas IgAl protease juga sangat menunjang pemahaman tentang patogenesis penyakit yang disebabkan infeksi ureaplasma. Dalam penelitian ini gen iga putatif Mycoplasma genitalium digunakan sebagai acuan untuk melacak gen iga U. urealyticum. Amplifikasi DNA ureaplasma dengan PCR menggunakan primer yang didesain kompatibel dengan gen iga putatif M. genitalium dilanjutkan sikuensing DNA, membuktikan adanya homologi sikuens nukleotida $100 \%$ seperti yang terekam pada data acuan (referensi). IgAl protease U. urealyticum adalah enzim seluler yang tidak disekresikan; ini dibuktikan dengan aktifitas enzim yang terdeteksi didalam sel, bukan di media kultur. IgAl protease telah terbukti merupakan protein integral membran sel dan digunakan untuk merusak IgA dipermukaan mukosa jaringan sehingga memungkinkan bakteri untuk mengkolonisasi mukosa dan menginduksi patogenesis penyakit. Penemuan ini mempunyai implikasi luas pada penanganan penyakit yang meliputi diagnosis dan terapi infeksi ureaplasma. (Med J Indones 2005; 14: 204-14)
\end{abstract}

\begin{abstract}
Bioassay of Ureaplasma urealyticum is necessary for detection as well as determination of pathogenic factors in order to understand the pathogenesis of diseases associate with ureaplasma infection. Cultivation and verification of ureaplasma is the first step of this study in the purpose of discovering sensitive method for ureaplasma detection. Cultivation of ureaplasma either in liquid or in solid media are able to detect the existence of ureaplasma in samples analyzed. However, application of PCR using specific primers to be compatible with urease gene (ure) would confirm the presence of ureaplasma. The pathogenicity of ureaplasma is potentially monitored using reporter gene as a marker for gene expression. IceC was chosen as reporter gene for ureaplasma pathogenic determination as the gene has great sensitivity, easily detectable and quantitated in simple method of ice nucleation assay. Transposon 916 (Tn916) was selected as a vector for iceC gene to transform ureaplasma. The application of recombinant Tn916-iceC which is considered as pUI, allow detection of ureaplasma activities when transform ureaplasma is tested by ice nucleation assay. It was expected that ureaplasma transformation is the manifestation of mutagenesis which interfere genes responsible for bacterial pathogenicity, in order pathogenesis of bacterial infection to be analyzed accurately. IgA1 protease is considered to be an important factor for ureaplasma pathogenicity as the enzyme is required for successful colonization. Identification of iga gene and determination of IgAl protease activity are important for understanding the pathogenesis of ureaplasma infection. Putative iga gene of Mycoplasma genitalium was used as a reference to identify the presence of iga nucleotide sequence in U. urealyticum. Convincing evidence were obtained after PCR amplification of ureaplasma DNA using primers designed to be compatible with putative iga gene of M. genitalium followed by the discovery of $100 \%$ sequence homology of amplified ureaplasma iga gene and iga gene of M. genitalium mentioned in establish data. IgAl protease activity of $U$. urealytium has been detectable in the cell rather than in media culture, suggesting that IgAl protease is not secreted out of cell. It was proofed that IgAl protease is membrane bound enzyme capable of digesting IgAl in mucosal tissues of various organs and considered as potential virulence factor for ureaplasma that cause disease or gain entry to mucosal membrane. The existence of IgA1 protease activity in bacterial plasma membrane would have implication in ureaplasma management such as diagnosis and therapy of ureaplasma infection. (Med J Indones 2005; 14: 204-14)
\end{abstract}

Department of Medical Biology, Faculty of Medicine, University of Indonesia, Jakarta, Indonesia
Keywords: Ureaplasma detection, Ureaplasma pathogenicity, IceC reporter gene, IgAl protease, $M$. genitalium putative gene. 
Ureaplasma urealyticum usually called ureaplasma is a species of microorganism belongs to family of Mycoplasma and class of Mollicutes. Ureaplasma has several characteristics which allow people to recognize it as being gram negative, nonmotile, microaerophyl, insensitive to penicillin and hydrolize urea to produce ammonia. Ureaplasma is one of pathogens responsible for diseases associate with infection of respiratory tract, lower genital tract and disturbances in utero. Various diseases in association with ureaplasma infection have been recognized. The diseases include uretritis and infertilities either in males or females, amnionitis and funisitis in pregnant women. The infection raises the risk of morbidity and mortality of neonates. ${ }^{1}$

Ureaplasma infection potentially interfere pregnancy course that may implicate to pathological conditions of either mother or born baby. It has been reported that ureaplasma infection often lead to spontaneous abortion, and in some cases the infection associate with maternal septisemia. Ureaplasma infection may also associate with premature of birth if the pregnant period is less than 37 weeks and the baby weigh less than 2500 gr. In progress cases, congenitally pneumoniae or acquired pneumoniae are mostly associated with chorioamnionitis which is considered due to ureaplasma infection. ${ }^{2}$

Clinical investigation on ureaplasma infection may find obstacles due to failures or difficulties in the management of patients or microorganisms involve. The result of ureaplasma infection is often asymptomatic or clinically silent during the initial course of infection. For example, endometrial infection with ureaplasma does not affect fetal development as the fetal membrane remain intact. However, the situation may implicate in the risk of morbidity and mortality of neonates. It was reported that ureaplasma has been isolated from six babies with serious intraventricular bleeding and from three babies who were suffering from hydrocephalus.

Additional problems in the therapy of ureaplasma infection is also making disappoinment so far, as the application of antibiotics which yield effective cure of infection have not been standardized yet. Suggestion on the therapy of ureaplasma infection is still inaccurate as the spectrum of diseases in babies suffering infection have not been clearly understood.

In consideration with the complicated management and monitoring of ureaplasma infection, early detection of
U. urealyticum from suspicious patients would be of advantageous for therapy and cure. Morover, an understanding of biological characteristics of $\mathrm{U}$. urealyticum is also necessary to prevent as well as to overcome the pathological consequences of infection.

This study is trying to develop the bioassay for U. urealyticum in the purpose of finding the strategic ideas and/or basic understanding in order them to be advantageous for prevention and therapy of diseases associate with ureaplasma infection. The implementation of the study is carried out in 4 subsequent experiments which include :

\section{Development of sensitive method for U. urealyticum detection using molecular biology methods}

The experiment was inspired by the fact that accurate epidemiological data on cases associated with ureaplasma infection in Indonesia is not available so far. The investigation of ureaplasma infection in Indonesia used to be done by Tjokronegoro. ${ }^{3}$ The study was dealing with the effect of U. urealyticum infection on semen quality of infertile couples. He cultured seminal fluid of infertile husbands in A3 media for the detection of U. urealyticum. Unfortunately he found inaccuracy for the ureaplasma detection, since other microorganisms capable of metabolizing urea instead of U. urealyticum is also potentially grow in A3 media. Morover, the method took longer time to obtain the desired results, as it required $1-4$ days for the investigation of growth sign as shown by the changes of media color due to $\mathrm{pH}$ increasing.

The application of polymerase chain reaction (PCR) for the detection of ureaplasma yields prospective accurate result more quickly than traditional culture technique. PCR is a technique to amplify a particular DNA segment from a certain DNA source. The application of PCR for the detection of U. urealyticum require primers which is designed to be compatible with urease structural gene. A pair of primers U4 and U5 have been designed to amplify a DNA fragment of 429 bp representing part of urease gene of all ureaplasma serotypes.

In this study the effectiveness of ureaplasma detection by traditional culture methods either in solid or liquid media was compared to molecular biology method of PCR. The study involves the detection of ureaplasma from samples of seminal fluid from infertile males. The accurate results obtained in this study would be 
useful for the sensitive method of ureaplasma detection potentially applied to overcome the pathological problems of patients under treatment.

\section{Determination of ureaplasma pathogenicity by means of creating genetic transformation of $U$. urealyticum through the insertion of reporter gene (iceC) mediated by transposon Tn916}

In this study the application of "reporter gene" for monitoring ureaplasma infection is potentially effective for the determination of ureaplasma pathogenesis in genetic point of view. The insertion of gene marker into ureaplasma would allow alteration of gene expression which could be determined subsequently by the application of indicator. In this context, the expression of gene responsible for bacterial pathogenicity is interrupted by the expression of gene marker or reporter gene as shown by indicator.

Ideally molecular indicator is composed of gene which existence and expression are allowed to be tested simply by the determination of gene transcription and/or translation activities. Ice or ina gene is a gene marker responsible for ice nuclei formation; its expression has been proofed to be a sensitive and efficient markers for bacterial gene activities. The gene used to be invented as part of normal vegetation commensals which is considered as the most sensitive marker in various publications. ${ }^{4,5}$

The ice gene expression is detectable quantitatively through the application of freeze dot assay on aluminum foil which has been set below $0^{\circ} \mathrm{C}$ in freezing water bath containing alcohol. The assay only need dilution, while the result is obtained within minutes. The gene marker might be inserted into transposon, a DNA fragment capable of moving from one site to another within a genome. In this study Tn916 was used as mutagene, in addition to iceC gene carrier as the gene is able to insert solely without duplication in a random manner, becoming stable and turn to transposition very rarely. ${ }^{6,7}$ Prior to the application of iceC-Tn916 recombinat (pUI) for ureaplasma mutagenesis, the pUI was used for the induction of E. coli S17-1 mutagenesis in a preliminary study.

\section{Identification of iga gene responsible for $\mathbf{U}$. urealyticum pathogenicity}

Studies on several bacteria responsible for developing meningitis, such as Haemophylus influenzae, Neisseria meningitidis and Streptococcus pneumoniae indicated that the bacteria produced IgA1 protease responsible for destroying human IgA1. It was concluded therefore that $\operatorname{IgA} 1$ protease is a virulence factor associate with the invasive disease owing to infection of bacteria under investigation. ${ }^{8}$

To understand the role of $\operatorname{IgA} 1$ protease in the pathogenesis of diseases associate with mycoplasma or ureaplasma infection, Kapatais et $\mathrm{al}^{9}$ investigated the activity of $\operatorname{Ig} \mathrm{A}$ protease in various species of mycoplasma and ureaplasma which infect human and animals. The results indicated that ureaplasma isolated from human urogenital tract recognized and digested human $\operatorname{Ig} \mathrm{A} 1$, however human $\operatorname{Ig} \mathrm{A} 2$ and $\operatorname{Ig} \mathrm{A}$ of rabbits, pigs and dogs were unrecognized and undigested. Likewise, ureaplasma isolated from animals such as cats, birds and cows were unable to hydrolize human IgA1. It could be concluded therefore that ureaplasma are able to produce IgA protease, although the specificity is limited to $\operatorname{IgA}$ of species hosting the ureaplasma.

The consequences of ureaplasma infection varies in males, females and babies as stated in publications. The role of iga gene in the manifestation of ureaplasma pathogenicity is important, since the expression of this gene produce enzyme capable of destroying IgA1 in the mucosa allowing ureaplasma to counter the host immune system and colonize the genital or respiratory tract successfully. Although the existence of iga gene expressing $\operatorname{IgA} 1$ protease have been identified in N. miningitidis, $\mathrm{H}$. influenzae and S. pneumoniae, ${ }^{8}$ and the putative iga gene with sequence homology to iga gene of $\mathrm{H}$. influenzae was also identified in M. genitalium, ${ }^{10}$ the existence of this gene in U. urealyticum was not identified and understood exactly so far.

This study aimed to identify and to isolate iga gene from U. urealyticum which is assumed to have homology to iga putative gene of M. genitalium. In the future the result of this study is expected to be useful for the determination and discovery of factors capable of interfering the structure and activities of this gene in the purpose of discovering effective control mechanisms for ureaplasma pathogenicity.

\section{The expression of $\operatorname{IgA1}$ protease and its activity in U. urealyticum}

This experiment desires an understanding of the mechanism of IgA1 protease in mediating U. urealyticum 
pathogenicity. An understanding of ureaplasma pathogenicity is important for the management of ureaplasma infection as well as controlling the contiguous spreading in the population. To achieve this understanding, it is necessary to determine factors which lead ureaplasma to become pathogenic microorganism.

In order ureaplasma to become pathogenic, it should be capable of colonizing host urogenital mucosa. The most important factors which leads ureaplasma colonization is the role of protease enzyme potentially breaks $\operatorname{IgA} 1{ }^{11,12} \operatorname{IgA} 1$ is believed to be the front defense system of the host to resist the invaders via mucosa. It is a protein secreted by the host immune system which is able to block adhesin secreted by pathogens on behalf of its adhesion on mucosal tissues. Apparently the first step of ureaplasma pathogenesis is the disruption of $\operatorname{IgA} 1$ in the purpose of overcoming the host defense mechanism prior to colonizing urogenital tract mucosa. ${ }^{13}$

In this study ureaplasma culture in liquid media is subjected to examination of IgA1 protease activity. The enzyme activity is going to be tested on its ability to break human IgA1. The study includes lysis or breaking of ureaplasma cells, testing the $\operatorname{IgA} 1$ protease activity of ureaplasma lysates by reacting to human IgA1 or alternative substrate.

An understanding on the mechanism of $\operatorname{Ig} \mathrm{A} 1$ protease in the pathogenesis of ureaplasma infection would be useful for searching new generation of drugs in the future. As IgA1 protease is bacterial rather than body (host) product, it would be recognized specifically without any cross reaction with body components. Therefore, this method would also beneficial for the detection of other pathogen producing IgA1 protease.

\section{METHODS}

\section{The development of sensitive method for ureaplasma detection}

The effectiveness of ureaplasma detection by traditional culture methods either in solid or in liquid media were compared to those detected by PCR method. The study included the detection of ureaplasma from 30 samples of seminal fluid from infertile males.
U. urealyticum standard strain ATCC 27618 was used for positive control. Samples for ureaplasma detection were semen of patients who served themselves for infertility examination in the Department of Medical Biology, Faculty of Medicine, University of Indonesia. Cultivation of ureaplasma in liquid media was carried out in Eppendorf tubes containing liquid media. The composition of liquid media was : $20 \mathrm{~g} / \mathrm{l}$ Micoplasma Broth Base (BBL), $30 \mathrm{~g} / \mathrm{l}$ Trypticase Soy Broth (BBL); 0,2 $\mathrm{g} / \mathrm{l}$ DNA; 0,15 $\mathrm{g} / \mathrm{l} \mathrm{CaCl}_{2}$ and $1,7 \mathrm{~g} / \mathrm{l}$ Putrescine dihydrochloride. This mixture was dissolved in double distilled water and adjusted the $\mathrm{pH}$ to 5.5 with $2 \mathrm{~N} \mathrm{HCl}$. The solution was sterilized by autoclaving at $121^{\circ} \mathrm{C}$ for 15 minutes. Subsequently the solution was enriched by the addition of $30 \%$ Mycoplasma supplement (Difco) or 20\% non-heat inactivated horse serum (Gibco BRL), $29 \mathrm{~g} / \mathrm{l}$ Urea agar Base (BBL), $1 \%$ urea; $0,8 \% \mathrm{MnCl}_{2} ; 5 \mathrm{ml} / \mathrm{l}$ of $2 \%$ L-cystein, and $1000 \mathrm{IU} / \mathrm{ml}$ penicillin or $250 \mathrm{ug} / \mathrm{l}$ amphicillin. The standard strain of $\mathrm{U}$. urealyticum ATCC 27618 and ureaplasma samples (semen) were taken aseptically for $100 \mathrm{ul}$ and transferred to Eppendorf tubes which have been filled with liquid media. The tubes were closed and sealed perfectly with parafilm, after which the culture were incubated at $37^{\circ} \mathrm{C}$. Changes of media color was monitored every 24 hours up to 4 days. The growth was considered positive as the media became red because of the presence of phenol red as a marker of cell (ureaplasma) growing. Cultivation of ureaplasma in solid media was initiated by the preparation of solid media with the composition of $7.5 \mathrm{~g}$ Noble agar plus $500 \mathrm{ml}$ liquid media. The solvent was sterilized by autoclaving in the same way as has been done for liquid media. The media was poured into petri dishes, so that each dish received $7 \mathrm{ml}$ of agar mixture respectively. As the media become solid, standard ureaplasma (ATCC 27618) as well as semen samples were taken aseptically for $50 \mathrm{ul}$ and dropped it on agar medium in petri dishes. These bacterial drops were spread on agar surface entirely, and subsequently incubated in gas pack which has been completed with anaerobic indicator. The cultures were monitored everyday until the fourth day of incubation. As there were colonies detectable, the assay was continued by adding $\mathrm{MnCl}_{2}$-urea and allowed it to react for 5 minutes at room temperature. The ureaplasma colonies yielded "fried egg" pattern with dark brown color in the center, when it was checked microscopically in the magnification of 50 to 100 times. 
Prior to urease (ure) gene amplification by PCR, ureaplasma DNA from liquid culture of $8-12$ hour incubation was isolated by standard method available. The DNA yield was eventually subjected for ure detection by PCR, using a method developed by Teng et al. ${ }^{14}$

\section{Transformation of ureaplasma by means of reporter gene (iceC) insertion, mediated by transposon Tn916.}

The recombinant plasmid carrying transposon Tn916 and iceC gene was received from donors as a small inoculum of E. coli culture in an agar stab. The first step of gene processing was propagation of recombinant plasmid by subculturing the bacterial clone in an agar plate containing LB broth, and was continued by subculturing E. coli growth in solid media into liquid media which has been added the appropriate concentration of antibiotics (tetracycline for iceC propagation; amphyicillin and erythromycin for Tn916 propagation). The cultures were incubated by vigorous shaking at $37^{\circ} \mathrm{C}$ overnight. Bacterial growth was observed when the broth is becoming turbid.

The plasmid carrying Tn916 and iceC gene were extracted from bacterial culture in subsequent processes: sedimentation of bacteria by centrifugation, lysis of bacterial cells using lytic solution available, extracted DNA from the lysates using phenolchloroform-isoamyl alcohol (25:24:1) and precipitated the DNA with cold ethanol. Tn916 and iceC DNA inserts were separated from recombinant plasmids by digestion of the plasmids with restriction enzymes appropriate for the cloning site of DNA (Tn916 DNA was separated from pAM120 by digestion with HinC II, while the iceC DNA was separated from pJL1703 by digestion with EcoRI). The digestion mixtures were electrophoresed on $0.8 \%$ agarose at $90 \mathrm{~V}$ for an hour. The insert band were cut from from the gel with a sterile surgery blade in such a way so that the DNA were taken with as minimal adherent gel as possible. The cut gel were subsequently electroeluted in a cellophan bag containing TAE buffer, and run at $90 \mathrm{~V}$ for an hour. The insert DNA were recovered by precipitating the electroeluted buffer with $100 \%$ ethanol and processed them according to standard method available.

The purified Tn916 were utilized as a vector for iceC reporter gene to transform the target cells (U. urealyticum). Prior to cell transformation the purified
Tn916 and iceC gene were ligated by reactions involving creation of blunt end DNA and ligase mediated reaction, according to manual prescription available. ${ }^{15}$ The new recombinant DNA Tn916-iceC was recognized as pUI. pUI was subsequently utilized for ureaplasma transformation. However, before ureaplasma transformation was constructed, transformation of E. coli S17-1 was done for a preliminary study in the purpose of technical effectiveness.

E. coli S17-1 or U.urealyticum culture at logarithmic phase $\left(\mathrm{OD}_{390}=0.6\right)$ were allowed to be competent cells by incubation the cells with $\mathrm{CaCl}_{2}$ according to method suggested by Maniatis et al, 1985). Competent cells was mixed with $20 \mathrm{ul} \mathrm{pUI}$ and incubated in ice bath for 20 minutes. The tube containing the competent cells and pUI was transferred to $42^{\circ} \mathrm{C}$ water bath for 50 seconds, afterward return it to $0^{\circ} \mathrm{C}$ ice bath for 2 minutes, to make heat shock condition for transformation. The mixture was added with $800 \mathrm{ul}$ of sterile LB broth $\mathrm{pH} 7.2$ and incubated it at $37^{\circ} \mathrm{C}$ for 30 minutes in water bath. Finally $100 \mathrm{ul}$ of transform E. coli S17-1 was spread on solid LB agar containing the appropriate antibiotics and incubated at $37^{\circ} \mathrm{C}$ overnight, while the ureaplasma culture was stored at $4^{\circ} \mathrm{C}$ overnight prior to use it for ice nucleation assay.

\section{Methods for iga gene identification}

This study will be performing iga gene identification of U. ureallyticum by employing the putative iga gene of $\mathrm{M}$. genitalium as a reference and probe. The putative iga gene of M. genitalium has been proofed previously to have great homology $(51.3 \%)$ with iga gene of H. influenzae. ${ }^{10}$ iga gene identification will be conducted in a standard strain of $\mathrm{U}$. urealyticum ATCC 27618. Putative iga gene of M. genitalium was also purchased from ATCC with a code of MG219 inserted into plasmid pUC18, and was addopted to E. coli SURE2.

The study was done in sequence, beginning with the cultivation of ureaplasma in liquid media in the same way as the previous study in which the growth was verified by the PCR amplification of ure gene. In the mean time E. coli SURE2 was cultured for pUC18 carrying MG219 propagation; this putative gene was separated from plasmid by digestion with restriction enzymes BamH1 and EcoR1. The pure MG219 was isolated from gel electrophoresis using "glassmix" kit (Sigma L) and was used as DNA probe after being labelled with digoxygenin. The labelled probe was 
utilized for ureaplasma iga gene detection by Southern blot hybridization of ureaplasma genome which has been isolated from liquid ureaplasma culture. The ureaplasma iga gene was also identified by PCR amplification of ureaplasma genome by employing primers which were designed to be compatible with putative iga gene of $\mathrm{M}$. genitalium. The primers were designed using data from website VIRTUAL GENOME CENTER. The PCR product was also used as a probe for ureaplasma genome identification by Southern blot hybridization. Finally the PCR product was sequenced to confirm the iga gene of ureaplasma. The sequencing of DNA and its analysis was carried out with the assistance of Eijkman Institute, Jakarta.

\section{Methods for examination of ureaplasma IgA1 protease expression and activity}

Ureaplasma pellet of $200-400 \mathrm{ml}$ culture containing $10^{7}$ cells was dissolved in 140 ul buffer B containing $1 \mathrm{mM}$ phenyl methane sulfonyl fluoride (PMSF) and $2 \%$ Triton X-100 to make up a total volume of $200 \mathrm{ul}$. The mixture was incubated at $37^{\circ} \mathrm{C}$ for 30 minutes and was subsequently centrifuged at $17.000 \mathrm{~g}$ for 30 minutes at $4^{\circ} \mathrm{C}$. The supernate or liquid phase was separated into new sterile microfuge tube, while the pellet was mixed again with 200 ul buffer B plus PMSF and Triton X-100. The mixture was centrifuged again in the same condition as before. The supernate was aspirated into new sterile tube, designated as detergent phase, while the pellet was redissolved with the previous solution to make up the final volume of 15 ul. 15 ul of liquid phase, detergent phase and pellet suspension were mixed with 3 ug human $\operatorname{IgA} 1$ and incubated at $37^{\circ} \mathrm{C}$ overnight. Samples were electrophoresed on SDS-PAGE and the results were visualized with $\mathrm{Ag}$ attaining.

\section{RESULTS}

The growth of U. urealyticum in either liquid or solid media took time of $1-7$ days. The growth was detectable as the culture media turned the color from yellow to light green in the presence of bromothymol blue or red in the presence of phenol red as indicator. The colonies of ureaplasma in solid media looked gold brown belt around the colony when the culture was observed under the dissecting microscope. Observation on culture of semen from infertile men indicated positive growth in 7 out of 30 samples examined. To make sure interpretation that ureaplasma growth exactly in culture, PCR amplification of ureaplasma ure gene utilizing specific primers was carried out. The PCR results of ure gene from standard ureaplasma ATCC 27618 was analyzed by investigating the amplified DNA in agarose gel electrophoresis as shown in Figure 1.

Figure 1 show the PCR result of ure gene using primers and methods suggested by Teng et al (1994). The DNA band of $458 \mathrm{bp}$ representing ure gene of ureaplasma was detectable. The PCR results of ure gene from semen samples of infertile patients indicated 5 out of 30 samples were ureaplasma positive as $458 \mathrm{bp}$ band representing ure gene of ureaplasma were detectable in each positive sample.

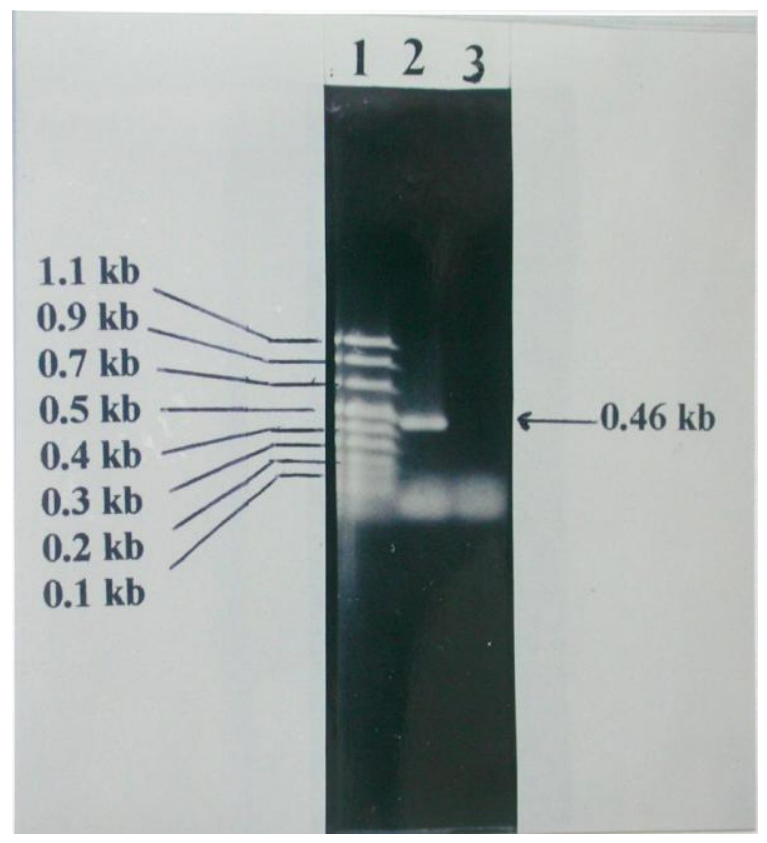

Figure 1. The PCR results of ure gene of ureaplasma genome from U. urealyticum ATCC 27618 detected in gel electrophoresis, using primers and method suggested by Teng et al, 1994.

Verification of plasmid carrying iceC gene, transposon Tn916 and the ligation results of both DNA is necessary to be chekked in order the results to be eligible. The electrophoretic pattern of this verification was shown in Figure 2. The ligation of pAM120-Hind III (Tn916) and iceC gene yielded a new recombinant DNA called pUI which give rise band of $32.3 \mathrm{~kb}$ in gel electrophoresis.

The induction of pUI for mutagenesis of E. coli S17-1 and U.urealyticum ATCC 27618 was examined by ice 
nucleation assay. The transformants was prepared in various dillution after which the dilution mixtures were dropped on aluminum foil coated with margarine and freezed in ice bath containing ethanol. The formation of ice was noted in different temperature ranging from $-1^{\circ}--13^{\circ} \mathrm{C}$ as shown in Table 1 and 2 .

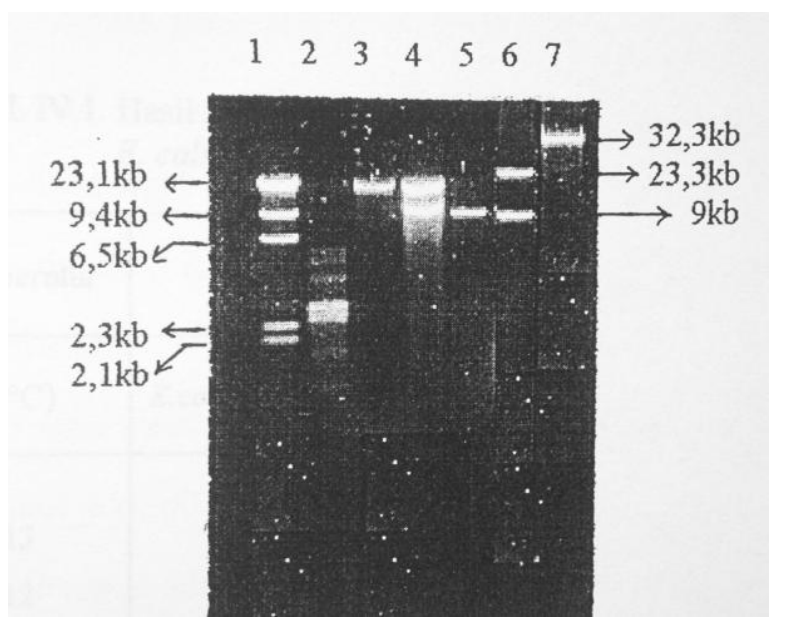

Figure 2. Gel electrophoresis of plasmids, reporter gene, transposon and $p U I$ recombinant.

Lane 1. Marker II ( $\lambda$ DNA-Hind III).

2. pAM120 - Hinc II.

3. pAM120 - Hind III.

4. pJL1703-EcoR1.

5. ice $C$ gene.

6. ice C gene and pAM120 - Hind III.

7. pUI.

Table 1. Results of ice nuclei activity assay in E. coli (pJL 1703 : : iceC; E. coli S17-1 (pUI : : iceC) and E. coli S17-1 (pUC19).

\begin{tabular}{cccc}
\hline \multirow{2}{*}{$\begin{array}{c}\text { Temperature } \\
\left({ }^{\circ} \mathrm{C}\right)\end{array}$} & \multicolumn{3}{c}{ Number of ice nuclei / Cells } \\
\cline { 2 - 4 }$(\mathrm{pJL} 1703::$ iceC $)$ & $\begin{array}{c}\text { S17-1 } \\
(\mathrm{pUI}:: \text { iceC })\end{array}$ & $\begin{array}{c}\text { S17-1 } \\
(\mathrm{pUC19})\end{array}$ \\
\hline-13 & $4.3 \times 10^{-3}$ & $5.6 \times 10^{-3}$ & -- \\
-12 & $6.4 \times 10^{-4}$ & $7.5 \times 10^{-4}$ & -- \\
-11 & $3.2 \times 10^{-4}$ & $5.2 \times 10^{-4}$ & -- \\
-10 & $1.9 \times 10^{-4}$ & $4.7 \times 10^{-4}$ & -- \\
-9 & $6.3 \times 10^{-5}$ & $8.2 \times 10^{-4}$ & -- \\
-8 & $4.7 \times 10^{-5}$ & $7.4 \times 10^{-5}$ & -- \\
-7 & $1.3 \times 10^{-6}$ & $1.6 \times 10^{-5}$ & -- \\
-6 & -- & -- & -- \\
-5 & -- & -- & - \\
-4 & -- & -- & -- \\
-3 & -- & -- & -- \\
-2 & -- & - & -- \\
-1 & -- & - & - \\
\hline
\end{tabular}

Table 2. Results of ice nucleation assay on the transformation of U. urealyticum with pUI.

\begin{tabular}{|c|c|c|}
\hline \multirow[b]{2}{*}{$\begin{array}{c}\text { Temperature } \\
\left({ }^{\circ} \mathrm{C}\right)\end{array}$} & \multicolumn{2}{|c|}{ Number of ice nuclei / Cells } \\
\hline & $\begin{array}{c}\text { U. urealyticum } \\
(\mathrm{pUI})\end{array}$ & $\begin{array}{c}\text { U. urealyticum } \\
\text { (pUC19) }\end{array}$ \\
\hline-13 & 7.54 & -- \\
\hline-12 & 6.18 & -- \\
\hline-11 & 3.62 & -- \\
\hline-10 & 2.04 & -- \\
\hline-9 & 1.26 & -- \\
\hline-8 & 0.75 & -- \\
\hline-7 & -- & -- \\
\hline-6 & -- & -- \\
\hline-5 & -- & -- \\
\hline-4 & -- & -- \\
\hline-3 & -- & -- \\
\hline-2 & -- & -- \\
\hline-1 & -- & -- \\
\hline
\end{tabular}

The putative iga gene of M.genitalium isolated from E.coli SURE2 was verified before it was employed as a reference for designing primers, or as probe for Southern hybridization in later investigation. After plasmid isolation, digestion of pUC10 carrying putative iga gene with BamH1 and EcoR1 yielded a DNA fragment of $34.7 \mathrm{~kb}$ representing putative iga gene MG219. By the verification completed, the gene was labeled and utilized for Southern hybridization of iga gene of U. urealyticum. Specific bands were detectable following hybridization of labeled MG219 gene to EcoR1 fragments of ureaplasma genome in Southern blot as shown in Figure 3. This hybridization suggested the presence of sequence homology to putative iga gene in ureaplasma.

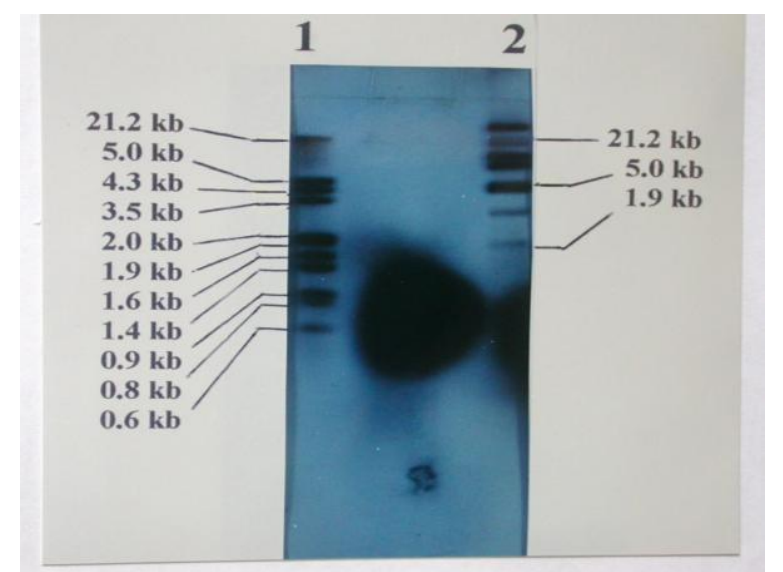

Figure 3. Southern hybridization of putative iga gene MG219 with EcoRl fragments of $U$. urealyticum DNA genome. 
The PCR amplification of ureaplasma iga gene using primers designed from data of putative iga gene of $\mathrm{M}$. genitalium, yielded DNA band of $0.4 \mathrm{~kb}$ representing iga gene of U. urealyticum. This band was verified by DNA sequencing after reasonable recovery of amplified DNA was obtained. The nucleotide sequence of this PCR amplified DNA from ureaplasma show 100\% homology with those of putative iga gene of $\mathrm{M}$. genitalium as shown in Figure 4.

SDS-PAGE of U. urealyticum lysates including liquid phase, detergent phase and pellets were shown in Figure 5. All three samples derived from liquid phase, detergent phase and pellet suspension were able to show $\operatorname{IgA} 1$ protease activity, while sample from culture media did not show enzyme activity. SDSPAGE with $\mathrm{Ag}$ staining from the three samples indicated $\mathrm{Fc}$ and $\mathrm{Fab}$ fragments of 35.7 and $32.32 \mathrm{kDa}$ as a result of $\operatorname{IgA} 1$ digestion by $\operatorname{IgA} 1$ protease. The intensity of the bands were higher in liquid and detergent phase rather than that in undissolve phase (pellet suspension). Ureaplasma cells which were treated with Triton X-100 were consistently show IgA1 protease activity in their supernates as indicated by the presence of bands representing $\mathrm{Fc}$ and $\mathrm{Fab}$ fragments in SDS-PAGE. This pattern was similar with that in control Igase treated with $0.1 \%$ Triton $\mathrm{X}$ 100.

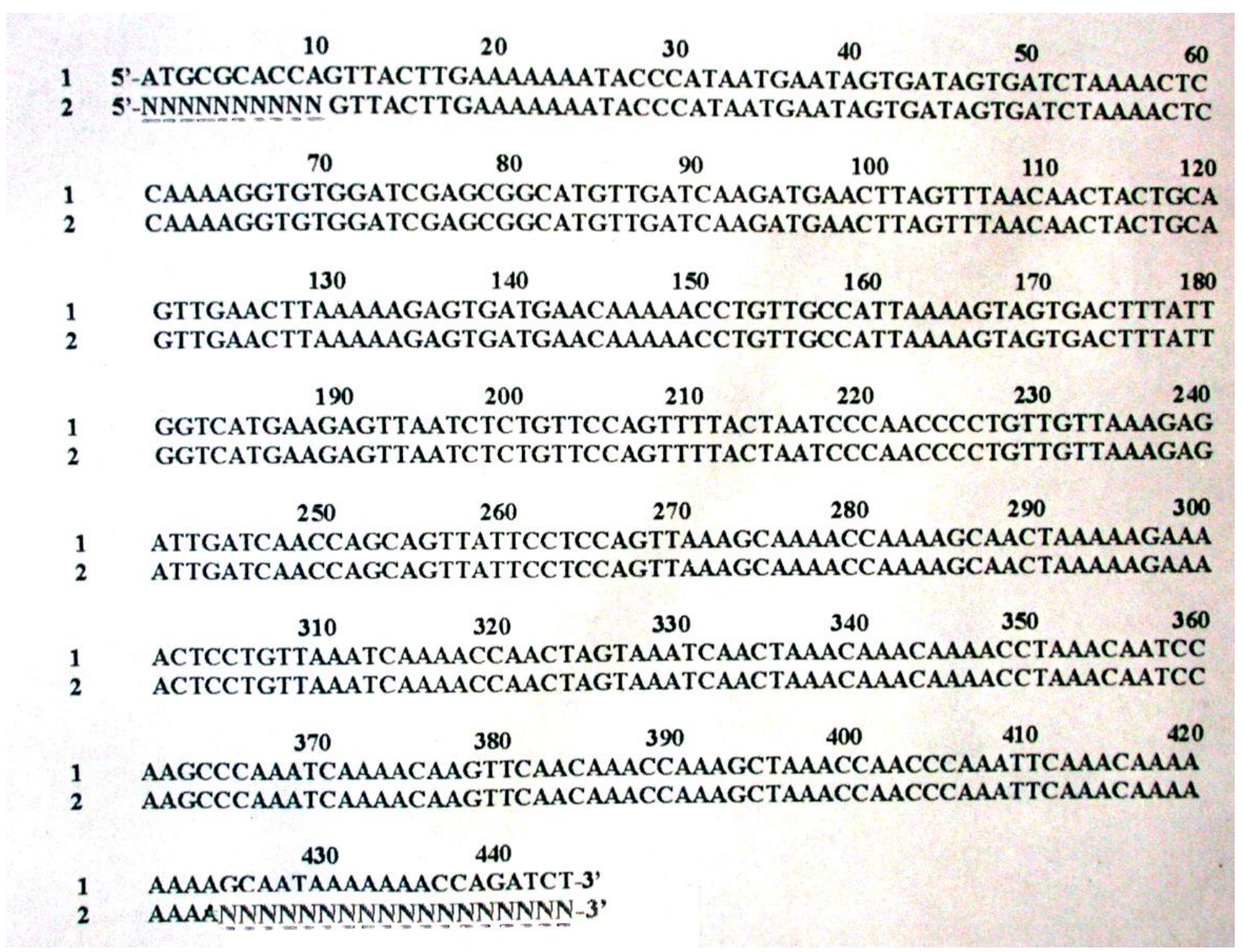




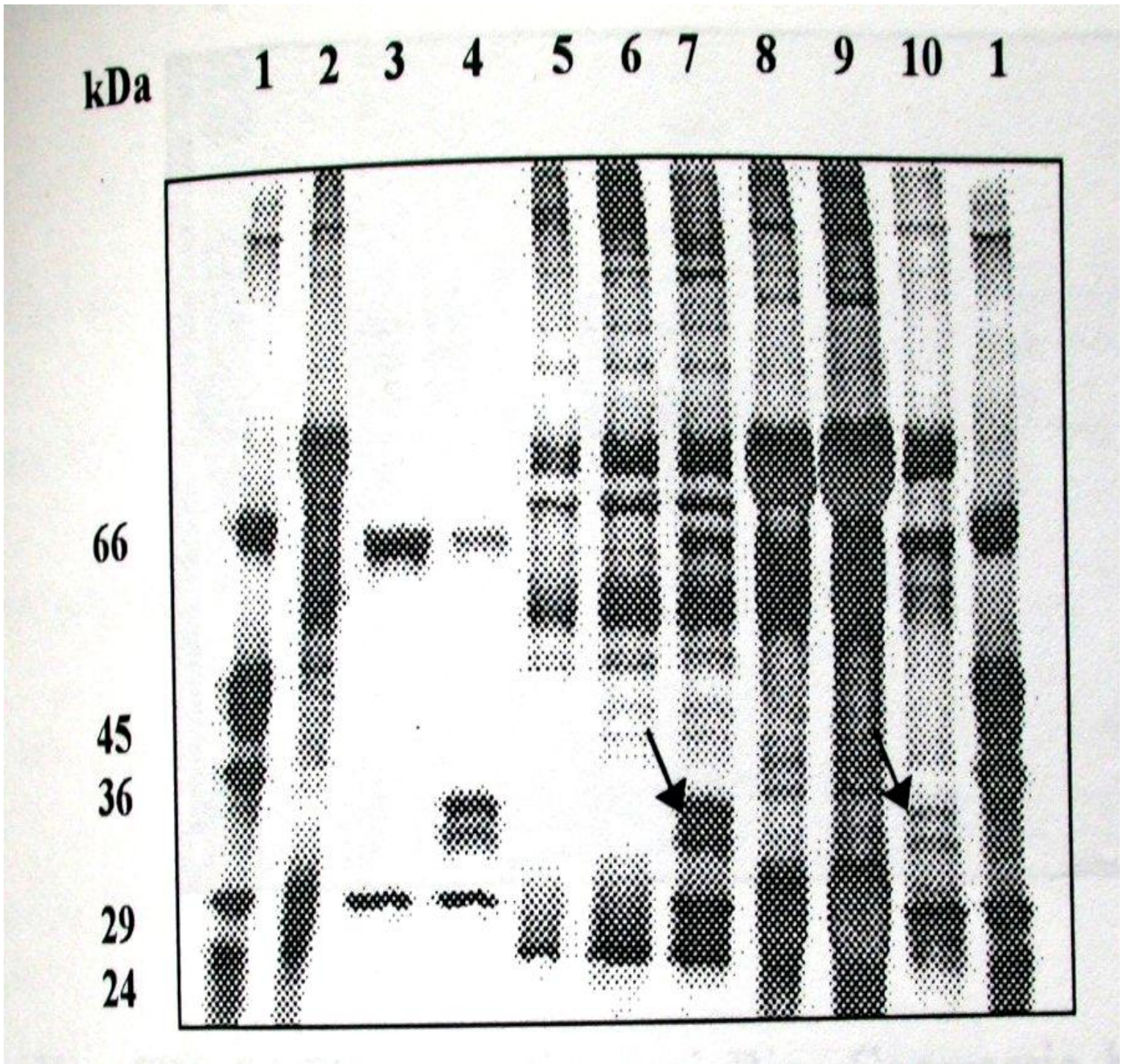

Figure 5. SDS-PAGE of ureaplasma cell lysates which was obtained by cell fractionation using Triton X-100, stained by Ag. Fractions derived from either liquid or detergent phases (dissolved fractions) or pellet (undissolved fraction) show IgA1 protease activities as indicated by bands representing Fc and Fab fragments (arrows).

Lane 1, protein marker SDS 7 (Sigma)

2, intact ureaplasma cells

3, IgA1 + PBS buffer

4, IgA1 + Igase

5, Dissolved fraction- $2 \mathrm{ul}$

6, Dissolved fraction- $4 \mathrm{ul}$

7, $\operatorname{Ig} \mathrm{A} 1+$ dissolved fraction

8, Undissolved fraction- 2 ul

9, Undissolved fraction- 4 ul

10, $\operatorname{Ig} \mathrm{A} 1+$ undissolved fraction 


\section{DISCUSSION}

Cultivation and verification of $U$. urealyticum is the first step of this study to explore pathogenicity factors of ureaplasma in the purpose of discovering bioassay for detection and control mechanisms of ureaplasma infection. Cultivation of ureaplasma in liquid and solid media with slight modifications have been studied and promoted for ureaplasma investigation in the future. The modification was performed in adaptation to our laboratory facilities and conditions. It was shown that successful achievememt of cultivation require intensive care in every step of work, otherwise failure of cell recovery occur at the end of cultivation. The growth and fertility of ureaplasma culture was indicated by the changes of media color, although the turbidity kept clear.

Detection of ureaplasma in samples by cultivation potentially show the presence of $U$. urealyticim in samples analyzed, however the presence of ureaplasma need to be confirmed accurately as there may be bacteria rather than ureaplasma present in the sample which give similar positive growth pattern. The application of PCR using specific primers compatible to ure gene of ureaplasma seems to comply with this reqirement. The PCR amplification of ure gene from semen samples of infertile patients using appropriate primers and method ${ }^{14}$ indicated 5 out of 30 samples were ureaplasma positive as $458 \mathrm{bp}$ band representing ure gene of ureaplasma were detectable in each positive sample. Samples which were positive with PCR detection were derived from samples with positive growth on cultivation examination. Nevertheless, samples which were positive on cultivation examination were not always positive on PCR examination. The results suggested that bacteria rather than ureaplasma in samples were potentially grow and give similar pattern, however they were definitely negative on ure gene PCR examination as their genome were not compatible with the primers specific for U. urealyticum. Therefore it could be suggested that PCR amplification of ure gene is more sensitive for ureaplasma detection than cultivation examination.

The presence of bacteria and their activities in natural inhabitants is detectable and potentially monitored using reporter gene as a marker of gene expression. In this context, the product of reporter gene expression should be easily measured and quantitated in controlled or desired condition. IceC gene is a reporter gene which activities could be monitored by ice nuclei assay. This gene has great sensitivity, easily detectable and quantitated as it does not require crucial processing instead of cascade dilution. Tn916 is selected as vector for iceC gene to transform bacteria of interest because $\mathrm{Tn} 916$ is potentially inserted in single position into bacterial genome and becoming stable without duplication and/or transposition. The application of pUI (recombinant of iceC gene and Tn916) to transform E. coli and U. urealyticum, give relatively similar results when monitored by ice nucleation assay. There were no ice nuclei formation in both species at the temperature heater than $-7^{\circ} \mathrm{C}$. It was expected that this mutagenesis interfere genes responsible for bacterial pathogenicity, in order pathogenesis of bacterial infection to be analyzed accurately.

Among pathogenic factors responsible for the development of diseases after bacterial infection is IgA1 protease. This enzyme has been identified and characterized in various bacteria including Neisseria gonorrhoeae, N. meningitides, Streptococcus pneumoniae, S. oralis, S. sanguis, S. mitis, Haemophilus influenzae, H. aegypticus, Prevotella sp. and Capnocytophaga sp. However, the existence and the role of $\operatorname{IgA} 1$ protease in U. urealyticum have not been proofed and understood so far. Iga gene is considered responsible for bacterial pathogenicity since the gene express IgA protease which hydrolize IgA on the mucosa of different organs in order to facilitate bacteria to colonize the appropriate site. The purpose of this study is to identify and isolate iga gene from ureaplasma to unravel its role in ureaplasma pathogenicity. Putative iga gene of M. genitalium was used as probe for Southern hybridization of ureaplasma genomic DNA to proof the presence of iga nucleotide sequence in U. urealyticum. Convincing evidences were obtained after PCR amplification of ureaplasma DNA using primers designed to be compatible with putative iga gene of $\mathrm{M}$. genitalium followed by the discovery of $100 \%$ sequence homology of amplified ureaplasma iga gene and iga gene of $\mathrm{M}$. genitalium mentioned in establish data (Virtual Genome Center Internet).

This study also suggested that $\operatorname{IgA} 1$ protease activity of $\mathrm{U}$. urealyticum has been detectable in the cell rather than in media culture. It was proofed that $\operatorname{IgA} 1$ protease of ureaplasma is membrane bound protein capable of digesting mucosal tissues of various organs. The potential enzyme activity of ureaplasma to counter host immune system, represent the important capacity of ureaplasma to express its 
pathogenic effect upon infection. IgA1 protease produced by $\mathrm{U}$. urealyticum is considered to be potential virulence factors for the bacteria as the enzyme activities allow the bacteria to cause disease or gain entry at mucosal membrane. Since IgA1 protease of ureaplasma is membrane bound enzyme, the presence of cells in sufficient amount in the site of infection is becoming a prerequisite for successful colonization. Ureaplasma infection becomes asymptomatic when the cells are in small amount or spread everywhere in the body. This situation make an effort for monitoring ureaplasma infection become difficult, as the assay for ureaplasma infection require samples of adequate bacterial population.

\section{CONCLUSION}

The results of this study emphasize that the diagnosis of ureaplasma infection should be confirmed by the detection of $\mathrm{U}$. urealyticum in samples besides of discovering markers of enzyme activities or gene products. Since the microbes are often in small quantities, yet the cultivation is strictly difficult, the application of PCR using appropriate primers is considered to be the best choice for U. urealyticum detection.

In consideration that $\operatorname{Ig} \mathrm{A} 1$ protease is an important factor for pathogenesis of ureaplasma infection, the application of new generation of drugs capable of halting $\operatorname{IgA} 1$ protease activity will be an effective mean for therapy and cure of diseases associate with ureaplasma infection.

\section{Acknowledgment}

The study presented in this paper was supported by URGE Project Batch II 1995/1996 No. 035/HTPP/II/URGE/1995. The author would like to express his appreciation to Felix M. Mesak, Yovita H. Aris and Dwi Anita Suryandari for their contribution in Laboratory works and developing ideas for this study to completion.

\section{REFERENCES}

1. Cassell GH, Waites KB, Crouse DT, Ruud PT, Canupp $\mathrm{KC}$ et al. Association of Ureaplasma urealyticum infection of the lower respiratory tract with chronic lung disease and death in very-low-birth-weight infants. The Lancet 1998; $7: 2400$ - 04.

2. Likitnikul S, Kusmiesz H, Nelson JD, McCracken GH. Role of genital mycoplasmas in young infants with suspected sepsis. J Pediatrics 1986; 109: 971 - 74.

3. Tjokronegoro A, Ayuningtyas D, Ganjar L. Pengaruh TMycoplasm (Ureaplasma urealyticum) terhadap semen pria pasangan infertil. Maj Kedokt Indones 1993; 43 : $223-33$.

4. Lindgren PB, Frederick R, Govindarejan AG, Panapoulus NI, Staskawiez BJ, Lindow SE. Applied and environmental microbiology. Emb J 1989; 8 : 1291 - 99.

5. Lindow SE. Competitive exclution of epiphytic bacteria by ice Pseudomonas syringae and Erwinia herbicola. J Bacteriol 1989; $153: 2520-57$.

6. Harrero M, Lorenzo V, Timis KW. Transposon vectors containing non-antibiotic resistance selection foreign markers for cloning and stable chromosomal insertion of foreign genes in gram negative bacteria. J Bacteriol 1990; $172: 6557-67$.

7. Wilson KJ, Sessitch L, Guller Ad, Kermans A, Jefferson RA. $\beta$-glukoronidase (gus) transposon for ecological and genetic studies of Rhizobia and other gram negative bacteria. J Microbiol 1995; 141 : 1691 - 705.

8. Lomholt H, Poulsen K, Kilian M. (1995). Comparative characterization of the iga gene Encoding IgA1 protease in Neisseria meningitides, Neisseria gonorhoeae and Haemophilus influenzae. Mol Microbiol 1995; 15 : 495 - 506.

9. Kapatais ZK, Chandler DK, Barile MF. Survei of immunoglobulin A protease activity among selected species of Ureaplasma and Mycoplasma: specificity for host immunoglobulin A. Infect Immunol 1985; 47:704-09.

10. Fraser CM, Gocayne JD, White O, Adams MD, Clayton RA, Fleishman RD. The minimal gene complement of Mycoplasma genitalium. Science 1995; 270 : 397 - 403.

11. Kilian M, Thomsen B, Petersen TE, Bleeg HS. Occurence and nature of bacterial IgA proteases. Ann NY Acad Sci 1984; $409: 612$ - 24 .

12. Robertson JA, Stemler ME, Stemke GW. Immunoglobulin A protease activity of Ureaplasma urealyticum. J Clin Microbiol 1984; $19: 225$ - 58 .

13. Hajishengallis G, Nikolova E, Russel MW. Inhibition of Streptococcus mutants adherence to saliva coated hydroxypatite by human secretory immunoglobulin A (SIgA) antibodies to cell surface protein antigen I/II: reversal by $\operatorname{IgA} 1$ protease cleavage. Infect Immun 1992; $60: 5057-64$.

14. Teng LJ, Zheng XT, Glass JI, Watson HL, Tsai J, Cassell GH. Ureaplasma urealyticum biovar specificity and diversity are encoded in multiple-banded antigen gene. J Clin Microbiol 1994; 32 : 1464 - 69.

15. Maniatis T, Fritsch EF, Sambrook Y. Molecular cloning : A laboratory manual. $2^{\text {nd }}$ ed. Cold Spring Harbor Laboratory Press, New York, 1982. 
